УДК: 27.058 .57

Т. М. Децюк, к. пед. н., доцент,

Г. О. Кедровська, студентка

\title{
РЕСОЦІАЛІЗАЦІЇ КОЛИШНІХ ЗАСУДЖЕНИХ ДО УМОВ СУЧАСНОГО СУСПІЛЬСТВА
}

Актуальність теми дослідження. Не дивлячись на те, що останнім часом значна увага держави приділяється вдосконаленню пенітенціарної системи, питання ресоціалізації колишніх засуджених так і залишається не достатньо вирішеним.

Постановка проблеми. У процесі ресоціалізації соціально-психологічна робота із колишніми засудженими передбачає надання високо кваліфрікованої допомоги, під час якої здійснюється видозміна особистісної спрямованості. Але на практиці заходи, що сприяють ресоціалізації колишніх засуджених, фрактично не проводяться, або носять суто умовний характер.

Аналіз останніх досліджень i публікацій. Ресоціалізацію колишніх засуджених розглядають у своїх працях такі науковці як В. Наливайко, О. Осауленко, А. Козуб, О. Мироняк, Н. Кривоконь, Т. Сила, Л. Жук, О. Неживець, В. Шахрай, В. Кибальченко.

Виділення недосліджених частин загальної проблеми. Не дивлячись на значний науковий доробок, проблема ресоціалізації колишніх засуджених до умов сучасного суспільства залишається маловивченою і потребує подальшого дослідження.

Постановка завдання. Проаналізувати наукові підходи до поняття «ресоціалізація колишніх засуджених», а також визначити напрями та форми ресоціалізації колишніх в'язнів для установ соціальної сорери.

Виклад основного матеріалу. Процес трансформації особистості під час $i$ після виконання покарань є результатом комплексної взаємодії багатьох фракторів, а саме імпортації, соціалізації, депортації і культурної еволюції та ін. Даний процес занадто складний, щоб аналізувати його лише в площині адаптації чи реабілітації. Саме термін «ресоціалізація» найбільш повно відображає процеси, які відбуваються з засудженими у в'язниці і після звільнення з неї.

Висновки. Найактуальнішою дефрініцією процесу входження в суспільство колишнього засудженого є ресоціалізація, що являє собою певний процес фрормування в особи позитивних рис, що сприяють відмінному від попереднього ставленню до людини, суспільства, праці, традицій, норм моралі, тобто, є своєрідним змістом повторного становлення особистості, виправлення.

Ключові слова: ре соціалізація; ресоціалізація колишніх в'язнів; пенітенціарна ре соціалізація; постпенітенціарна ресоціалізація.

T. M. Detsiuk, Candidate of Pedagogical Sciences, Associate Professor

H. O. Kedrovska, Student

\section{RESOCIALIZATION OF FORMER CONVICTS TO THE CONDITIONS OF MODERN SOCIETY}

Urgency of the research. Despite the fact that recently the state pays considerable attention to improving the penitentiary system, the issue of re-socialization of former convicts still remains unresolved.

Target setting. In the process of resocialization, socio-psychological work with former convicts involves the provision of highly qualified assistance, during which a change in personal orientation takes place. But in practice, measures to promote the re-socialization of former convicts are not actually carried out, or are purely conditional.

Actual scientific researches and issues analysis. Such scientists as V. Nalyvaiko, O. Osaulenko, A. Kozub, O. Myroniak, N. Kryvokon, T. Syla, L. Zhuk, O. Nezhyvets, V. Shakhrai, $V$. Kybalchenko consider the resocialization of former convicts in their works. 
Uninvestigated parts of general matters defining. Despite significant amount of scientific works, the problem of resocialization of former convicts to the conditions of modern society remains poorly studied and needs further research.

The research objective. To analyze scientific approaches to the concept of "resocialization of former convicts", as well as to determine the directions and forms of resocialization of convicts for social institutions.

The statement of basic materials. The process of transformation of personality during and after the execution of punishments is the result of a complex interaction of many factors, namely importation, socialization, deportation and cultural evolution, etc. This process is too complex to be analyzed only from the point of adaptation or rehabilitation. It is the term "resocialization" that most fully reflects the processes that take place with convicts in a prison and after their release.

Conclusions. The most relevant definition of the process of a former convict entering the society is resocialization, which is the process of formation of positive traits in a person that contribute to a different attitude to a human, society, work, traditions, moral, i.e., is a kind of re-formation, correction of personality.

Keywords: resocialization; resocialization of former prisoners; penitentiary resocialization; postpenitentiary resocialization.

DOI: 10.25140/2412-1185-2019-2(14)-26-33

Актуальність теми дослідження. Не дивлячись на те, що останнім часом значна увага держави приділяється вдосконаленню пенітенціарної системи, питання ресоціалізації колишніх засуджених так і залишається не достатньо вирішеним.

У осіб, звільнених з місць позбавлення волі, виникає одразу низка серйозних проблем, серед яких: проблема працевлаштування, відсутність житла, проблеми зі здоров'ям, втрата соціальних зв'язків, відсутність документів та інші. Частково неспроможність вирішення проблем викликані суб'єктивними факторами, тобто спричинені специфічними особистісними якостями колишнього в'язня, що сформувалися в процесі відбування покарання. Вони як правило перешкоджають відновленню та зміцненню соціальних зв'язків, успішному вирішенню питань щодо працевлаштування та проживання, матеріального забезпечення на початковому етапі перебування на волі. Але є ряд перешкоджаючих факторів, що не залежать від особистості колишнього засудженого, такі як: негативне ставленням до них у суспільстві, стигматизація, недовіра близьких та інші. Якщо колишній засуджений опиняється на одинці з величезною кількістю проблем, з якими не може самотужки впоратися, і не має підтримки, допомоги з боку інших людей чи організацій, може відбутися рецидив і людина знову скоює злочин, щоб опинитися в місцях позбавлення волі. Кількість злочинів, які скоєні повторно, свідчить про недосконалість системи соціальної роботи з колишніми засудженими, а зокрема щодо їх ресоціалізації.

Постановка проблеми. У процесі ресоціалізації соціально-психологічна робота із колишніми засудженими передбачає надання високо кваліфікованої допомоги, під час якої здійснюється видозміна особистісної спрямованості. Соціальна робота має фоокусуватися на відновленні соціальних зв'язків, повноцінній психокорекції та роботі 3 індивідуально-психологічними якостями колишнього правопорушника, а також відновленні громадянської позиції в житті. Але на практиці заходи, що сприяють ресоціалізації колишніх засуджених, фактично не проводяться, або носять суто умовний характер.

Аналіз останніх досліджень і публікацій. Проблема ресоціалізації колишніх засуджених викликає інтерес науковців з різних галузей наук. Зокрема, науковці В. Наливайко та О. Осауленко досліджували кримінологічні проблеми ресоціалізації колишніх ув'язнених. Дослідження А. Козуб присвячено аналізу поняття «ресоціалізація», а також напрямам державної політики, щодо ресоціалізації осіб, звільнених з місць позбавлення волі. Різні аспекти процесу ресоціалізації засуджених та колишніх ув'язнених аналізують у своїх наукових доробках такі вчені як О. Мироняк, Н. Кривоконь та Т. Сила. Теоретичні засади соціальної та трудової ресоціалізації осіб, що звільнилися з місць позбавлення визначають Л. Жук та О. Неживець. Структура технології соціальної роботи з колишніми засудженими представлена у науковому 
доробку В. Шахрай. Проблеми пенітенціарної теорії та практики, зокрема ресоціалізацію колишніх засуджених у своїх працях розглядає В. Кибальченко.

Виділення недосліджених раніше частин загальної проблеми. Не дивлячись на значний науковий доробок, проблема ресоціалізації колишніх засуджених до умов сучасного суспільства залишається маловивченою і потребує подальшого дослідження. Більшість наукових праць присвячені питанню ресоціалізації саме осіб, які відбувають покарання, а інститутом ресоціалізації виступають місця позбавлення волі, проте наш науковий інтерес становить ресоціалізація осіб, які звільнилися з місць позбавлення волі.

Постановка завдання. Проаналізувати наукові підходи до поняття «ресоціалізація колишніх засуджених», а також визначити напрями та фрорми ресоціалізації колишніх в'язнів для установ соціальної сфери.

Виклад основного матеріалу. В сучасному нестабільному світі, який швидко змінюється, дуже тяжко пристосовуватися до нових умов, а тим більше тим особам, які довгий час знаходилися в стані соціальної ізоляції, а саме в місцях позбавлення волі.

На межі XX і XXI століть науковці дійшли висновку, що проблема виконання кримінальних покарань $€$ багатоманітною та складною, але по суті $€$ соціально-педагогічною проблемою адже головною її соціальною метою виступає ресоціалізація засуджених, тобто певний процес перевиховання осіб з метою повноцінного повернення їх у суспільство в статусі «колишніх ув'язнених».

Перш ніж аналізування особливості ресоціалізації колишніх ув'язнених, розглянемо сам термін «ресоціалізація». Поняття «ресоціалізація» широко використовується як у кримінології, соціології, психології так і в інших гуманітарних науках. Він об'єктивно пов'язаний з таким поняттям як «соціалізація», що означає інтеграцію індивіда в соціум, входження особи в суспільство через прийняття його певних норм, принципі, правил, що дозволяє даному індивіду ефективно фрункціонувати. Префікс «ре» означає відновлення чи повторність дії певної дії, відповідно ресоціалізацію можна розглядати як повернення індивіда у суспільство, повторне засвоєння необхідних для нормального функціонування у конкретному соціумі навиків, норм, правил поведінки та ін.

Процес трансформаційних змін особистості у процесі і після виконання покарань $\epsilon$ результатом комплексної взаємодії багатьох чинників, серед яких імпортація, соціалізація, депортація і культурна еволюція. Саме тому цей процес занадто складний, щоб аналізувати його лише в площині адаптації чи реабілітації [1]. Поняття «ресоціалізація», на наш погляд, найбільше влучно відображає всі вищеперераховані трансформаційні процеси особистості, які відбуваються з засудженими під час відбування покарання, так і після звільнення з ув'язнення.

Термін «ресоціалізація» вперше був законодавчо закріплений в Україні лише в 2004 році. Відповідно до ст. 6 Кримінально-виконавчого кодексу України, під ресоціалізацією слід розуміти свідоме відновлення засудженого в соціальному статусі як повноправного члена суспільства, а також повернення його до самостійного загальноприйнятого соціально-нормативного життя в суспільстві. Виправлення засудженого виступає необхідною умовою ресоціалізації [2].

Поняття «ресоціалізація» широко розкривається в словнику-довіднику для соціальних педагогів і соціальних працівників. Під «ресоціалізацією» слід розуміти відновлення особистістю певних якостей, що необхідні для нормальної життєдіяльності в соціумі, засвоєння особистістю нових ролей, цінностей, навичок замість попередніх, а також комплекс заходів, що спрямований на відновлення соціального статусу особи, втрачених чи недостатньо сформованих соціальних навичок, переорієнтація соціальних і референтних орієнтацій девіантів за рахунок включення їх у нові, позитивно орієнтовані стосунки та види діяльності. Близьким до даного визначення $€$ трактування «ресоціалізації щодо засуджених». Під даним поняттям розуміють відновлення, збереження й розвиток соціально корисних зв'язків і відносин особи, що є засудженою, як у період відбування нею покарання, так і на першому етапі її життя після звільнення 3 місць позбавлення волі [3].

Ресоціалізація, на думку Т. Сили, є складним багатоаспектним феноменом, що містить етапи, комплекси заходів, методики і техніки цілеспрямованого впливу на особистість, групи особистостей, організації, громади та суспільство в цілому, який можна розглядати, з одного боку, як теоретичний концепт, а з іншого - як сфреру практичної діяльності соціального працівника [4]. 
Науковець Н. Кривоконь розглядає ресоціалізація як складну соціально-правову категорію, що включає різні сторони оновлення соціальних зв'язків засуджених осіб. Дослідниця виділяє дві складові цього поняття, а саме: пенітенціарну та постпенітенціарну. Під пенітенціарною ресоціалізацією вона розглядає вироблення у особи, що перебуває в місцях відбування покарання, законослухняної поведінки. Постпенітенціарна ресоціалізація представляє собою комплекс заходів щодо встановлення соціальних зв'язків особи, що звільнилася з місць позбавлення волі, її трудового та побутового влаштування з метою подальшої соціальної реабілітації, що забезпечить відновлення в колишнього засудженого соціального статусу та сприятиме його поверненню до законослухняного життя [5]. При цьому пенітенціарну ресоціалізацію здійснюють як правило органи виконання покарань, а постпенітенціарну логічно мають здійснювати відповідні соціальні служби, але на практиці таких спеціальних організацій не існує.

Вивчаючи різні аспекти ресоціалізації колишніх в'язнів, О. Мироняк зауважує, що досягнення ресоціалізації є можливим лише у тому випадку, якщо у засудженого після звільнення будуть вирішені всі побутові та соціальні проблеми. Виходячи з цього, ми не можемо говорити про остаточну ресоціалізацію засудженого безпосередньо під час відбування покарання. На думку науковця, в умовах перебування особи у закладі відбування покарання можна лише зробити певні кроки для забезпечення досягнення ресоціалізації після її звільнення [6].

Нам імпонують погляди вищезазначених науковців. Під ресоціалізацією ми розглядаємо професійну діяльність спрямовану на сприяння повноцінного повернення в соціум осіб, які звільнилися 3 місць позбавлення волі. Тобто предметом нашого дослідження $\epsilon$ постпенітенціарна ресоціалізація колишніх засуджених.

Як зазначає О. Осауленко, ресоціалізація $€$ процесом фрормування у особи позитивних якостей та рис, що сприяютимуть поважному її ставленню до інших людей, суспільства, закону, праці, звичаїв, норм моралі, традицій та стимулюватимуть законослухняну поведінку [7]. Таким чином, ресоціалізація $\epsilon$ своєрідним змістом процесу виправлення, перевиховання, переорієнтації особистості щодо життя в соціумі.

Дослідники Л. Жук та О. Неживець, стверджують, що важливими складовими ресоціалізації $є$ трудова та соціальна. Ці складові включають заходи підготовки до звільнення з особами, що відбувають покарання, так і надання вже звільненим особам відповідної соціальної допомоги, створення можливостей для професійного навчання та працевлаштування, що сприятиме відновленню у них потрібних навичок і соціальних зв'язків для пристосування до загальноприйнятих умов життя у суспільстві [8]

Таким чином, постпенітенціарна ресоціалізація відіграє визначну роль в процесі повернення колишнього засудженого до повноцінного життя у суспільстві.

Кримінолог В. Наливайко зазначає, що поняття «ресоціалізація осіб, звільнених від покарань» поєднує в собі три аспекти: змістовий, психологічний та соціальний. Змістовий аспект характеризується сукупністю заходів, що спрямовані та перевиховання особи, її розвиток і самовдосконалення. Психологічний аспект включає обов'язкове врахування в процесі ресоціалізації особистих психологічних особливостей засудженого. Соціальний аспект включає сукупність всіх суспільних зв'язків колишнього засудженого [9].

Крім того, В. Наливайко запропонував ряд форм ресоціалізації осіб, що відбувають покарання та звільнених з місць позбавлення волі, а саме профілактика, психологічна корекція, соціально-правова терапія, соціальна реабілітація.

Відповідно профілактична діяльність має ґрунтуватися на виявленні та усуненні несприятливих психолого-педагогічних, психобіологічних, юридичних та інших факторів, що сприяють відхиленню у психічному, соціальному розвитку особистості та її поведінкових реакцій. Профрілактика включає в себе: інформування, роз'яснення щодо необхідності дотримання норм закону, суспільних правил поведінки; створення належних умов для вибору професії, отримання освіти, а також гармонійного, культурного розвитку особи; організація заходів, що сприятимуть забезпеченню формування позитивної життєвої позиції осіб, що звільнилися з місць позбавлення волі; заходи щодо соціального захисту колишніх засуджених.

Заходи психологічної корекції особи, що вчинила правопорушення, головним чином мають фокусуватися на усуненні негативного впливу соціального мікросередовища, що ії оточує, а також усуненні комунікативних труднощів, труднощів взаємодії з іншими. Ще один завданням даної форми ресоціалізації є формування активної життєвої позиції колишнього засудженого. 
Важливе значення має соціально-правова терапія, яка представляє сукупність заходів, спрямованих на: корекцію відхилень у поведінці на основі індивідуально-диференційованого підходу, що фокусуються на формуванні соціально схвальних моделей поведінки; визначення та аналіз типу та особливостей особистості колишнього засудженого, що характеризують ступінь соціальної дезадаптації; надання кваліфікованої допомоги у формуванні взаємин, що сприяють нормальній соціалізації.

Соціальна реабілітація як фрорма ресоціалізації колишніх засуджених, включає в себе систему організаційних, культурних, лікувальних, правових, освітніх, оздоровчих та інших заходів, що сприяють всебічному відновленню фізичного і морального стану особистості. Без соціальної реабілітації неможливе повернення колишніх в'язнів до повноцінного життя у суспільстві [9].

Отже, для повноцінного повернення особи, що звільнилася з місць позбавлення волі, до повноцінного суспільного життя ресоціалізація повинна включати в себе комплекс заходів спрямованих на: якісне інформування щодо змін в правовому та соціальному полі, на формування комунікативної компетентності, на встановлення нових соціально схвальних зв'язків, на формування нових цілей життя, на вибір професії та працевлаштування, на формуванні соціально схвальних паттернів поведінки, на відновлення фрізичного здоров'я та самооцінки особистості. Таким чином, ресоціалізація являє собою сукупність різних форм заходів, який має здійснюватися комплексно і узгоджено між собою, а отже потребує наявності певної інституції, що буде надавати перераховані послуги на безоплатній основі у співпраці із органами пенітенціарної системи. При цьому важливе гуманне, людяне ставлення, що відповідає головному принципу соціальної роботи - гуманізму. Отже, на нашу думку, дану діяльність з особами, що звільнилися з місць позбавлення волі має виконувати спеціальна соціальна служба, яка може бути як громадською організацією, що здійснюватиме свою діяльність за державним замовленням, або спеціально створена мережа державних соціальних служб для роботи з колишніми засудженими.

Щодо принципів роботи діяльності соціальних служб та правоохоронних органів із раніше засудженими особами, то науковець С. Наливайко виділяє наступні:

- принцип надання соціальної допомоги колишнім засудженим, незалежно від їх віку, національної приналежності, політичних чи інших переконань, соціального статусу, професії, місця проживання тощо;

- принцип гуманізму, тобто головною цінністю є людина;

- принцип симбіозу допомоги і самодопомоги, тобто важливим є поєднання зусиль фахівця із позитивним потенціалом особи та її активністю, прагненням до змін;

- принцип інтеграції передбачає об'єднання зусиль різних соціальних інституцій, які $\epsilon$ зацікавленими у позитивній особистісній трансформації колишнього засудженого та його продуктивній адаптації до життя у соціумі;

- принцип комплексного підходу означає використання широкого спектра прийомів, методів, засобів у вирішенні проблеми ресоціалізації колишнього засудженого державними, громадськими, приватними установами й організаціями;

- принцип етичності передбачає дотримання норм моралі та професійної етики, зокрема такого етичного принципу як конфіденційність, при роботі з колишніми засудженими;

- принцип поваги до особистості, що передбачає фокусування на позитивній динаміці змін в її розвитку;

- принцип взаємної довіри як основи ефективної професійної взаємодії у процесі ресоціалізації колишнього засудженого [9].

Варто зазначити, що у новій редакції Європейських пенітенціарних правил виділяється чотири головні принципи, а саме: гуманізму, поваги до людської гідності, соціальної орієнтованості та ефективності управління [10].

Отже, на нашу думку, головними принципами соціальної роботи щодо ресоціалізації колишніх засуджених $€$ гуманізм, толерантність, комплексний підхід та віра в позитивні зміни особи та наснаження. Важливо, щоб фахівці, які працюють з колишніми засудженими, бачили в них в першу чергу людину, а не злочинця, вірили в кожного і надихали своїх клієнтів на позитивні зміни у їх житті. 
Формування якісної системи ресоціалізації колишніх засуджених залежить від політики держави. Науковець А. Козуб, здійснила аналіз пріоритетних напрямків соціальної політики України щодо ресоціалізації осіб, що звільнилися з місць позбавлення волі, до них належать:

1. Реалізація соціальних програм щодо соціальної адаптації колишніх в'язнів, що пов'язана зі встановленням нормальних соціальних зв'язків і стосунків особи з соціумом. До цього напряму відносяться також культурно-освітні програми щодо професійної підготовки та перепідготовки осіб, що відбули покарання та виявили бажання у здобутті освіти; лікувально-оздоровчі заходи для тих, хто потребує надання медичної допомоги у зв'язку із погіршеним здоров'я внаслідок набутих в установах відбування покарання захворювань тощо.

2. Впровадження програм 3 психологічної адаптації 3 метою фрормування у особи, яка звільнилася 3 місць позбавлення волі, стандартів та правил поведінки, соціальних норм, існуючих в суспільстві і втрачених нею під час перебування в соціальній ізоляції.

3. Втілення програм з трудової адаптації звільненого з місць позбавлення волі, що пов'язані із працевлаштуванням, професійною підготовкою та перепідготовкою, адаптацією до трудового колективу, формуванням позитивного ставлення колективу до нього, матеріальними та моральними методами заохочення до трудової діяльності.

4. Впровадження законодавчих проєктів щодо ресоціалізації осіб, що звільнилися 3 місць позбавлення волі. Таких, як розробка і прийняття Закону України «Про напрямки соціальної політики держави в сорері соціальної адаптації осіб, звільнених з місць позбавлення волі», розробка Програми щодо соціальної адаптації та ресоціалізації таких осіб тощо [11, с. 46].

Втілення соціальної політики щодо постпенітенціарної ресоціалізації осіб, що звільнилися 3 місць позбавлення волі, має здійснюватися через відповідні соціальні служби чи організації шляхом використання відповідних соціальних технологій. Науковець В. Шахрай, зазначає, що при розробці технологій соціальної роботи з колишніми засудженими слід враховувати наступні фрактори: ступінь деформації особистості в результаті впливу кримінальної субкультури; тривалість часу проведеного особою в соціальній ізоляції; кількість кримінальних покарань, які отримала особа, пов'язаних із позбавленням волі; наявність негативних особистих якостей, що сорормувалися в результаті режиму утримання засудженого в місцях позбавлення волі; рівень соціально-правової занедбаності особистості; особливості та настрої найближчого соціального оточення особи, насамперед сім'ї [12, с. 423].

Напрацювання технологій соціальної роботи з колишніми засудженими має відбуватися фахівцями установ соціального захисту, діяльність яких спрямована на постпенітенціарну ресоціалізацію. Крім напрямів роботи із колишніми засудженими, важливими, на наш погляд, будуть такі напрями як: соціальна робота із сім'єю колишнього засудженого; діяльність спрямована на зниження стереотипізації та таврування образу колишнього засудженого в соціумі; профрілактика такого явища, як романтизація способу життя осіб, які відбувають покарання в місцях позбавлення волі, та злочинного способу життя серед підлітків та молоді.

Проблема повернення до законослухняного життя дуже складна і вона стає ще більш складною, якщо людина була засуджена неодноразово і провела у місцях позбавлення волі довгий час. Відомо, що ізоляція від суспільства спричиняє втрату соціально корисних контактів і позбавляє самостійності у вирішенні побутових питань. Професійна допомога у подоланні соціальних та особистих проблем особам, які звільнилися з місць позбавлення волі, $є$ важливою умовою їх ефективної ресоціалізації, яка в свою чергу є запорукою уникнення рецидивних злочинів.

Висновки. Повернення колишніх засуджених до умов суспільного життя є складним і багатоаспектним феноменом, який має назву ресоціалізація. Заходи ресоціалізації, які впроваджуються в процесі відбування покарання особи в місцях позбавлення волі $\epsilon$ пенітенціарною ресоціалізацією, вони являють собою підготовку особи до звільнення. Постпенітенціарна ресоціалізація відбувається після звільнення особи і спрямована на повноцінне входження ії у суспільство. Серед основних принципів постпенітенціарної ресоціалізації є гуманізм, толерантність, комплексний підхід та віра в позитивні зміни особи та наснаження. Для підвищення ефективності даного виду ресоціалізації необхідно створення системи спеціальних соціальних установ. Подальшого дослідження потребує вивчення іноземного досвіду соціальної роботи щодо ресоціалізації колишніх засуджених. 
1. Ягунов, Д. В. Державне управління пенітенціарною системою України: механізм ресоціалізації засуджених: автореф. дис. канд. наук з держ. управління. / Д. В. Ягунов ; Одеський регіональний інститут держ. управління нац. академії держ. управління при Президентові України. Одеса, 2004. - 21 с.

2. Кримінально-виконавчий кодекс України / Відомості Верховної Ради України (ВВР), 2004 р. - № 3-4. - 21 с.

3. Словник-довідник для соціальних працівників та соціальних педагогів / уклад. О.В.Безпалько [та ін.] ; ред. А. Й. Капська [та ін.]. - К. : УДЦССМ, 2000. - 258 с.

4. Сила, Т. І. Міждисциплінарний зміст поняття «ресоціалізація» / Т. І. Сила // Збірник наукових праць Інституту психології імені Г. С. Костюка НАПН України. - Т ХІІІ, Ч. 1. - К., 2011. - С. 382-389.

5. Кривоконь, Н. І. Проблеми соціальної роботи та соціальної політики в Україні: навчальний посібник / Н. І. Кривоконь - Чернігів: ЧДТУ, 2012. - 320 с.

6. Мироняк, О. Деякі аспекти ресоціалізації засуджених та осіб звільнених з місць позбавлення волі / О. Мироняк // Соціальна політика держави у сфері запобігання злочинності та ресоціалізації осіб, які відбували покарання: матеріали IX міжвуз. наук. студ. конф. 3 кримінології та кримін.-викон. -4.3. - Нац. юрид. акад. України, 2011. - С. 33-34.

7. Осауленко, А. О. Становлення та розвиток поглядів на покарання та права і свободи засуджених (історико-правовий аспект) / А. О. Осауленко // Науковий вісник Ужгородського національного університету. Серія «Право». - № 21. - Т. 1., Ч. 1. - 2013. - С. 82-85.

8. Жук, І. Л. Сутність, показники та критерії ефективності праці засуджених в пенітенціарних установах України / І. Л. Жук, О. М. Неживець // Юридичний вісник. Повітряне і космічне право. - 2011. - № 1. - С. 88-91. - Режим доступу: http://nbuv.gov.ua/UJRN/Npnau_2011_1_22.

9. Наливайко, В. С. Кримінологічні проблеми ресоціалізації осіб, звільнених з місць позбавлення волі: автореф. дис. канд. юрид. наук: спец : 12.00 .08 / В. С. Наливайко; Нац. акад. внутр. справ України. - К., 2000. - 19 с.

10. Європейські пенітенціарні правила від 11 січня 2006 р. Рекомендація (2006) 2 Комітету Міністрів Ради Європи. - Донецьк : Донецький меморіал, 2006. - 36 с.

11. Козуб, А. Ресоціалізація осіб, які відбули покарання: поняття та напрямки державної діяльності / А. Козуб // Соціальна політика держави у сфері запобігання злочинності та ресоціалізації осіб, які відбували покарання: матеріали IX міжвуз. наук. студ. конф. з кримінології та кримін.-викон. права. Ч. 3. [за заг. ред. В. Голіни; ред. кол. А. Гетьман та ін.]. - Х. : Нац. юрид. акад. України, 2011. - С. 45-46.

12. Шахрай, В. М. Технології соціальної роботи: навчальний посібник / В. М. Шахрай. - К. : Центр навчальної літератури, 2006. - 464 с.

\section{References}

1. Yahunov, D. (2004) Derzhavne upravlinnia penitentsiarnoiu systemoiu Ukrainy: mekhanizm resotsializatsii zasudzhenykh [State management of the penitentiary system of Ukraine: the mechanism of resocialization of convicts]. Extended abstract of candidate's thesis. Odesa [in Ukrainian].

2. Kryminalno-vykonavchyi kodeks Ukrainy [Criminal Enforcement Code of Ukraine].

(2004). Vidomosti Verkhovnoi Rady Ukrainy - Bulletin of the Verkhovna Rada of Ukraine, 3-4, 21 [in Ukrainian]

3. Slovnyk-dovidnyk dlia sotsialnykh pratsivnykiv ta sotsialnykh pedahohiv [Dictionary-reference book for social workers and social educators]. (2000). Kyiv [in Ukrainian].

4. Syla, T. (2011). Mizhdystsyplinarnyi zmist poniattia «resotsializatsiia» [Interdisciplinary meaning of the concept of "resocialization"]. Zbirnyk naukovykh prats Instytutu psykholohii imeni H.S. Kostiuka NAPN Ukrainy; - Collection of scientific works of G. S. Kostyuk Institute of Psychology of the National Academy of Pedagogical Sciences of Ukraine, XIII (1), 382-389 [in Ukrainian].

5. Kryvokon, N. (2012). Problemy sotsialnoi roboty ta sotsialnoi polityky v Ukraini [Problems of social work and social policy in Ukraine]. Chernihiv: ChDTU [in Ukrainian].

6. Myroniak, O. (2011). Deiaki aspekty resotsializatsii zasudzhenykh ta osib zvilnenykh z mists pozbavlennia voli [Some aspects of re-socialization of convicts and persons released from prisons]. Sotsialna polityka derzhavy u sferi zapobihannia zlochynnosti ta resotsializatsii osib, yaki vidbuvaly pokarannia - Social policy of the state in the field of crime prevention and re-socialization of persons serving sentences: Proceedings of 9th interuniversity Scientific studying conference in Criminology and Forensics. (Vols. 3). (pp. 33-34). Kharkiv: National Law academy of Ukraine [in Ukrainian].

7. Osaulenko, A. (2013). Stanovlennia ta rozvytok pohliadiv na pokarannia ta prava i svobody zasudzhenykh (istoryko-pravovyi aspekt) [Formation and development of views on punishment and the rights and freedoms of convicts (historical and legal aspect)]. Naukovyi visnyk Uzhhorodskoho natsionalnoho universytetu. Seriia «Pravo» - Scientific Bulletin of Uzhhorod National University. Law series, 21 (1), $82-85$ [in Ukrainian].

8. Zhuk, I. (2011). Sutnist, pokaznyky ta kryterii efektyvnosti pratsi zasudzhenykh $\vee$ penitentsiarnykh ustanovakh Ukrainy [The essence, indicators and criteria of labor efficiency of convicts in penitentiary institutions of Ukraine]. Yurydychnyi visnyk. Povitriane $i$ kosmichne pravo - Legal Bulletin. Air and space law, 1, 88-91. Retrieved from http://nbuv.gov.ua/UJRN/Npnau_2011_1_22 [in Ukrainian].

9. Nalyvaiko, V. (2000). Kryminolohichni problemy resotsializatsii osib, zvilnenykh z mists pozbavlennia voli [Criminological problems of resocialization of persons released from prisons]. Extended abstract of candidate's thesis. Kyiv [in Ukrainian].

10. Yevropeiski penitentsiarni pravyla vid 11 sichnia 2006 r. Rekomendatsiia 2 Komitetu Ministriv Rady Yevropy [European Penitentiary Rules of 11 January 2006. Recommendation 2 of the Committee of Ministers of the Council of Europe]. (2006). Donetsk: Donetskyi memorialu [in Ukrainian].

11. Kozub, A. (2011). Resotsializatsiia osib, yaki vidbuly pokarannia: poniattia ta napriamky derzhavnoi diialnosti [Resocialization of persons who have served their sentences: concepts and directions of state activity]. 
Sotsialna polityka derzhavy u sferi zapobihannia zlochynnosti ta resotsializatsii osib, yaki vidbuvaly pokarannia - Social policy of the state in the field of crime prevention and re-socialization of persons serving sentences: Proceedings of 9th interuniversity Scientific studying conference in Criminology and Forensics. (Vols. 3). (pp. 45-46). Kharkiv: National Law academy of Ukraine [in Ukrainian].

12. Shakhrai, V. (2006). Tekhnolohii sotsialnoi roboty [Technologies of social work]. Kyiv [in Ukrainian].

Бібліографічний опис для цитування :

Надійшла 11.11.2019

Децюк, Т. М. Ресоціалізації колишніх засуджених до умов сучасного суспільства / Т. М. Децюк, Г. О. Кедровська // Проблеми соціальної роботи: фрілософія, психологія, соціологія. - 2019 - № 2 (14) - С. 26-33. 